\title{
ANALIZA PRZYDATNOŚCI ERATYKÓW POMORZA W BADANIACH CHRONOLOGII RECESJI OSTATNIEGO LAZDOLODU SKANDYNAWSKIEGO METODĄ IZOTOPÓW KOSMOGENICZNYCH
}

\author{
Analysis of Pomeranian erratics suitability for the study \\ of the last Scandinavian Ice Sheet recession with cosmogenic nuclides
}

\author{
KAROL TYLMANN*, PIOTR PAWEL WOŹNIAK**, VINCENT RINTERKNECHT ${ }^{\star * *}$
}

\begin{abstract}
Zarys treści. Wielkie eratyki położone in situ na powierzchni form morenowych mogą być obiektami datowania wieku ekspozycji metodą ziemskich izotopów kosmogenicznych (ang. terrestrial cosmogenic nuclides $-T C N$ ). Środkowe oraz wschodnie Pomorze jest regionem kluczowym z punktu widzenia uzupełnienia kosmogenicznej chronologii recesji ostatniego lądolodu skandynawskiego w północnej Polsce. Artykuł prezentuje metodę oraz wyniki selekcji głazów narzutowych na tym obszarze, pod kątem ich przydatności do datowania wieku ekspozycji metodą TCN. Proces selekcji wielkich eratyków przebiegał dwuetapowo. W pierwszej kolejności, z wykorzystaniem wszelkich dostępnych informacji, skonstruowano bazę GIS wielkich eratyków (254 obiekty), a następnie na podstawie rozmiarów i lokalizacji na cyfrowym modelu terenu oraz mapach geologicznych wytypowano przydatne głazy. W drugim etapie dokonano weryfikacji terenowej wybranych obiektów i 27 eratyków zakwalifikowano do datowania wieku ekspozycji metodą TCN. Znaczna redukcja głazów na poszczególnych etapach selekcji pokazuje wagę zaproponowanego w artykule systematycznego procesu selekcji. Rozmieszczenie wytypowanych głazów (skupienie na powierzchni wysoczyzn morenowych lub akumulacyjnych form marginalnych) oraz ich cechy indywidualne dobrze rokują dla wyników datowania wieku ekspozycji metodą TCN.
\end{abstract}

Slowa kluczowe: głazy narzutowe, datowanie metodą izotopów kosmogenicznych, lądolód skandynawski, Pomorze

\begin{abstract}
Large erratic boulders located in situ on moraines may be a target for surface exposure age dating with TCN (Terrestrial Cosmogenic Nuclides ). This paper presents the method and the results of the selection of erratics in Pomerania for this type of dating. Middle and eastern Pomerania are key regions to complete the cosmogenic chronologies of the geomorphology left by the last Scandinavian Ice Sheet retreat in the northern Polish landscape. Our selection of massive erratics consists of two stages. First, a GIS database (254 erratics) was constructed based on all available information about large boulders, and erratics were selected based on their dimensions and distribution against a digital elevation model and geologic maps. Second, field inspection of preliminarily selected boulders was conducted and 27 erratics were finally selected as suitable for surface exposure age dating with TCN. The significant reduction of the number of boulders at particular stages of qualification shows the importance of the proposed systematic selection. Spatial distribution of the selected boulders (location on moraine plateaux and paleo ice-marginal belts) and their individual features show their high usefulness for surface exposure age dating with TCN.
\end{abstract}

Key words: erratic boulders, terrestrial cosmogenic nuclide dating, Scandinavian Ice Sheet, Pomerania

\section{Wstęp}

Wielkie fragmenty litych skał, nierównomiernie rozmieszczone na powierzchni Niżu Europejskiego, od dawna budziły ciekawość geologów i były powodem ożywionych dyskusji naukowych, które w XIX wieku doprowadziły do sformułowania teorii zlodowaceń kontynentalnych (Agassiz 1837; Charpentier 1841). Nazywane eratykami (łac. errare - błądzić, erraticus - błądzący), głazami narzutowymi, bądź narzutniakami są jednymi z najbardziej charakterystycznych pozostałości po plejstoceńskich lądolodach. W okresie pionierskich

\footnotetext{
* Uniwersytet Gdański, Wydział Oceanografii i Geografii, Zakład Geologii Morza, al. Marszałka Piłsudskiego 46, 81-378 Gdynia; e-mail: k.tylmann@ug.edu.pl (autor korespondencyjny)

** Uniwersytet Gdański, Wydział Oceanografii i Geografii, Katedra Geomorfologii i Geologii Czwartorzędu, ul. Bażyńskiego 4, 80-952 Gdańsk; e-mail: geopw@ug.edu.pl

*** Université Paris 1 Panthéon-Sorbonne, Laboratoire de Géographie Physique, CNRS, UMR 8591, Francja; e-mail: vincent.rinterknecht@lgp.cnrs.fr
} 
badań nad zasięgiem zlodowaceń $\mathrm{w}$ drugiej połowie XIX wieku rozmieszczenie materiału eratycznego, pochodzącego z Fennoskandii i niecki Bałtyku, stanowiło jedno $\mathrm{z}$ istotnych kryteriów pierwszych rekonstrukcji kierunków napływu i rozprzestrzenienia mas lodowych w Polsce (Siemiradzki 1882). Ponadto narzutniaki zbudowane ze skał krystalicznych dostarczały interesującego materiału do studiów mineralogiczno-petrograficznych (Hermann 1911). Co więcej, eratyki zbudowane ze skał osadowych były i są do dziś istotnym źródłem skamieniałości wykorzystywanym w badaniach paleontologicznych, szczególnie w Niemczech (np. Rudolph 1994; Schallreuter 1994; Buchholz 2000), ale także i w Polsce (np. Stasińska 1967). Obecnie najatrakcyjniejsze (zazwyczaj największe) głazy narzutowe, jako pomniki przyrody nieożywionej, chronione są prawem i stanowią wartościowy element dziedzictwa geologicznego oraz potencjału geoturystycznego krajobrazu polodowcowego Polski (m.in. Makosz, Stanienda 2012; Woźniak i in. 2015; Górska-Zabielska 2015, 2016).

Materiał eratyczny występujący w osadach glacjalnych jest w Polsce od kilkudziesięciu lat wykorzystywany do rekonstrukcji kierunków transportu lądolodu skandynawskiego oraz charakterystyki petrograficznej różnowiekowych poziomów glin lodowcowych w ramach metody tzw. eratyków przewodnich (m.in. Czubla 2001, 2015; Czubla i in. 2006; Górska-Zabielska 2008; Woźniak, Czubla 2015). Głazy narzutowe znacznych rozmiarów położone na powierzchni terenu, co do których nie ma podejrzeń, że uległy przemieszczeniu po wytopieniu z lądolodu, bądź też zostały odsłonięte spod pokrywy osadowej, mogą być obiektami datowanymi przy pomocy izotopów kosmogenicznych (Dunai 2010). Technika ta, rozwijana intensywnie od końca lat 80 . XX wieku, pozwala na kalkulację czasu (w latach), jaki upłynął od odsłonięcia badanej powierzchnia skalnej spod lodu, a więc umożliwia datowanie momentu rozpoczęcia recesji lodowców i lądolodów (Ivy-Ochs, Briner 2014). W Polsce badania tego typu, przy zastosowaniu izotopu ${ }^{36} \mathrm{Cl}$ (Dzierżek i in. 1996, 1999; Dzierżek, Zreda 2007; Makos $\mathrm{i}$ in. 2013a, b) oraz izotopu ${ }^{10} \mathrm{Be}$ (Rinterknecht $i$ in. 2005; Makos i in. 2016) wykonywano od drugiej połowy lat 90 . XX wieku. Dotyczyły one zarówno recesji plejstoceńskich lodowców tatrzańskich (Dzierżek i in. 1999; Makos i in. 2013a, b,
2016), jak i zaniku ostatniego lądolodu skandynawskiego w północnej Polsce (Rinterknecht i in. 2005; Dzierżek, Zreda 2007).

Metoda ziemskich izotopów kosmogenicznych (ang. terrestrial cosmogenic nuclide - TCN) umożliwia bezpośrednie datowanie utworów polodowcowych budujących powierzchnie moren (Reuther i in. 2006). Stanowi ona istotne uzupelnienie dla metod pozwalających na pośrednie datowanie poziomów glacjalnych, takich jak metoda radiowęglowa, czy metoda OSL (Small $\mathrm{i}$ in. 2017). Jednak szereg ograniczeń, jakimi obarczone jest stosowanie izotopów kosmogenicznych $\mathrm{w}$ datowaniu recesji dawnych lądolodów sprawia, że staranny wybór odpowiednich stanowisk jest kluczowy z punktu widzenia wiarygodności otrzymywanych wyników. Artykuł prezentuje analizę wielkich głazów narzutowych występujących we wschodniej i środkowej części Pomorza pod kątem możliwości ich wykorzystania w tego rodzaju badaniach. Omówiono strategię oraz etapy selekcji potencjalnie przydatnych eratyków i finalnej kwalifikacji narzutniaków do datowania wieku ekspozycji metodą TCN.

\section{Czynniki wpływające na zawartość ziemskich izotopów kosmogenicznych w glazach narzutowych}

Ziemskie izotopy kosmogeniczne (np. ${ }^{10} \mathrm{Be}$, ${ }^{36} \mathrm{Cl},{ }^{26} \mathrm{Al}$ ) tworzą się w powierzchniowej warstwie skorupy ziemskiej w wyniku oddziaływania wtórnego promieniowania kosmicznego (powstającego w skutek reakcji promieniowania pierwotnego $\mathrm{z}$ atmosferą) $\mathrm{z}$ powierzchnią Ziemi (rys. 1). W rezultacie nieustannego „bombardowania” skał wysokoenergetycznymi cząstkami tego promieniowania izotopy niektórych pierwiastków (np. ${ }^{16} \mathrm{O},{ }^{28} \mathrm{Si},{ }^{35} \mathrm{Cl}$ ) przechodzą transformację do izotopów kosmogenicznych (np. ${ }^{10} \mathrm{Be},{ }^{36} \mathrm{Cl},{ }^{26} \mathrm{Al}$ ) (Ivy-Ochs, Kober 2008). Proces ich „narodzin” przebiega $\mathrm{w}$ określonym tempie, mierzonym $\mathrm{w}$ atomach/g/rok. Znając koncentrację izotopu kosmogenicznego w próbce skały oraz tempo jego produkcji, można obliczyć okres (w latach), przez który powierzchnia skalna wystawiona była na działanie promieniowania kosmicznego, a więc ustalić wiek jej ekspozycji (Kurtz, Brook 1994). 


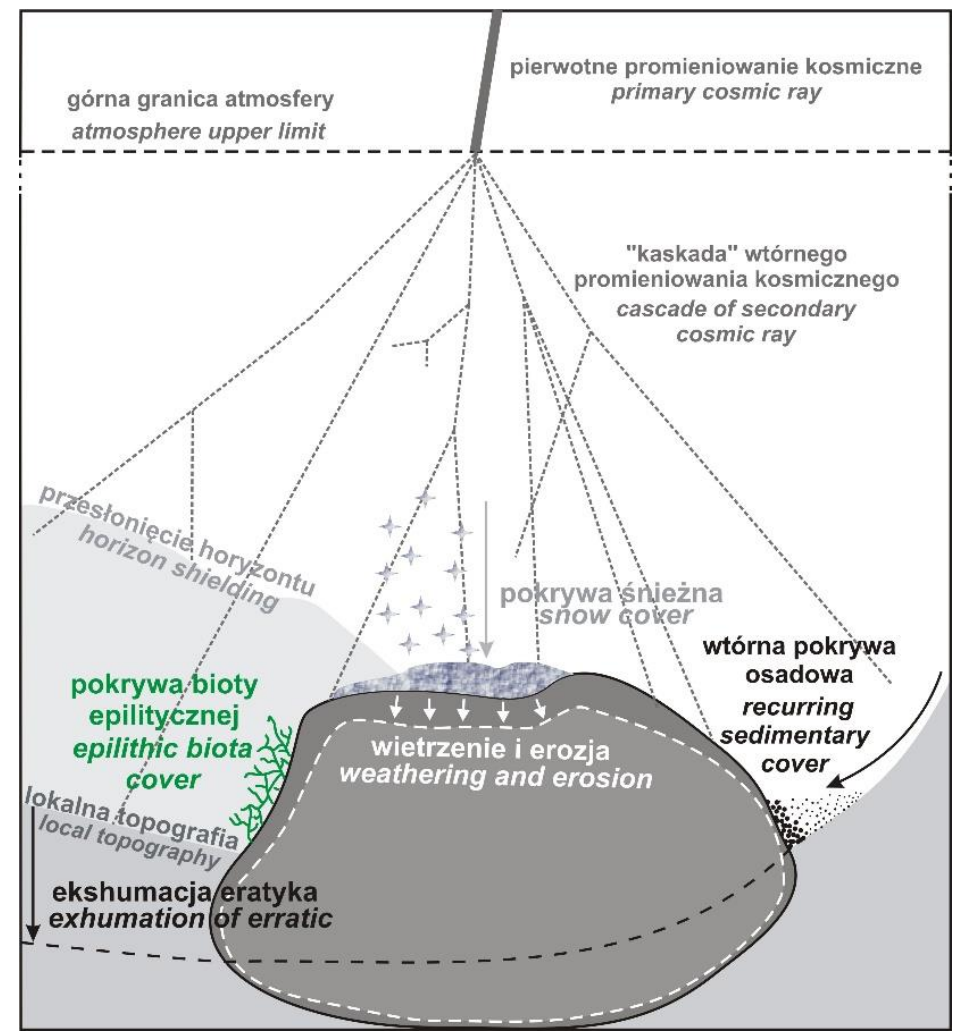

Rys. 1. Czynniki wpływające na wielkość wtórnego promieniowania kosmicznego docierającego do powierzchni eratyków oraz na przydatność głazów do datowania ekspozycyjnego metodą TCN

(na podstawie Dunai 2010 i Darvilla 2013, zmodyfikowane)

Factors influencing the secondary cosmic ray reaching erratic surface and the suitability of boulders for exposure dating with TCN (modified from Dunai 2010 and Darvill 2013)

„Kosmogeniczny zegar” zaczyna tykać w momencie odsłonięcia spod lodu zerodowanych glacjalnie wychodni skał lub eratyków. Erozyjna działalność lodu bazalnego nasyconego materiałem skalnym powoduje ścieranie powierzchniowej warstwy podłoża lądolodu oraz fragmentów skalnych transportowanych w stopie lądolodu. Skutkuje to usunięciem warstwy zawierającej izotopy kosmogeniczne powstałe we wcześniejszych okresach ekspozycji skał (tzw. izotopy odziedziczone). Dlatego istotne jest, by datowana powierzchnia nosiła ślady tego rodzaju działalności lądolodu, zwiększa to szansę na stwierdzenie, czy określony przy pomocy izotopów kosmogenicznych czas „startu zegara” jest równoważny z początkiem deglacjacji. Co więcej, głazy narzutowe datowane metodą TCN muszą znajdować się w naturalnej pozycji in situ, niezmienionej od momentu wytopienia z lądolodu. Eratyki dużych rozmiarów, położone na możliwie płaskiej powierzchni oraz częściowo osadzone w gruncie mają największą szansę spełniać to kryterium.

Jednak poza rozmiarem i lokalizacją geomorfologiczną głazów istnieje wiele czynników, które mogą wpływać na ich przydatność do datowania wieku ekspozycji, a w konsekwencji na wiarygodność otrzymywanych wyników (rys. 1). Osady zdeponowane na powierzchni głazu, pokrywa śnieżna lub roślinna może zmniejszyć natężenie promieniowania kosmicznego docierającego do skały i w rezultacie powodować niedoszacowanie wieku ekspozycji (Heyman i in. 2011). Symulacje wpływu pokrywy roślinnej (głównie korony drzew w obszarach zalesionych) pokazują, iż może ona powodować nieznaczną redukcję oddziaływania promieniowania kosmicznego rzędu 4\% (Cerling, Craig 1994) lub 3-7\% (Plug i in. 2007). Wpływ pokrywy śnieżnej kształtuje się zazwyczaj na podobnym poziomie. Przy warstwie śniegu o miąższości $75-150 \mathrm{~cm}$, zalegającej przez 4 miesiące $\mathrm{w}$ roku, redukcja produkcji ziemskich izotopów kosmogenicznych w powierzchniowej warstwie skały wynosi około 5\% (Dunai 2010). Średni okres zalegania pokrywy śnieżnej w środkowej i wschodniej części Pomorza jest obecnie znacznie krótszy i wynosi od 40 do 70 dni w roku, a średnia miąższość tej pokrywy kształtuje się na poziomie około 8-10 cm (Lorenc 2005). Zakładając nawet 
dłuższe okresy zalegania miąższych pokryw śnieżnych w późnym glacjale i w chłodnych okresach holocenu, wydaje się, że mogło to spowodować redukcję wpływu promieniowania kosmicznego jedynie rzędu kilku procent. Znacznie bardziej istotne może okazać się osłonięcie eratyka warstwą osadów. Warstwa piaszczysta o miąższości $1 \mathrm{~m}$, zalegająca na narzutniaku przez okres kilkunastu tysięcy lat, może spowodować niedoszacowanie jego wieku ekspozycyjnego o około 30\% (Rinterknecht i in. 2014). Dlatego też, jako obiekty datowania wieku ekspozycji metodą $\mathrm{TCN}$, preferowane są eratyki zlokalizowane na wyniosłościach terenu, gdzie ryzyko zalegania tego typu pokryw jest zminimalizowane.

Drugim istotnym czynnikiem wpływającym na zawartość ziemskich izotopów kosmogenicznych w narzutniakach jest erozja ich powierzchni zachodząca już po wytopieniu głazu z lądolodu (rys. 1). Również ona może przyczynić się do niedoszacowania wieku ekspozycji. Niszczenie powierzchni skały powoduje usunięcie części badanego izotopu, a wówczas jego koncentracja zmierzona w próbce nie będzie odpowiadać całkowitej koncentracji wynikającej z czasu ekspozycji. Zakładane często w literaturze maksymalne tempo erozji narzutniaków granitoidowych rzędu $1,3 \mathrm{~mm} /$ tys. lat (Gosse i in. 1995; Rinterknecht i in. 2012, 2014), w przypadku powierzchni o wieku rzędu kilkudziesięciu tysięcy lat, powoduje „odmłodzenie” o około 2$8 \%$. Redukcja natężenia promieniowania kosmicznego docierającego do powierzchni eratyka (a w konsekwencji niedoszacowanie wieku ekspozycji) może być także spowodowana osłonięciem horyzontu wynikającym $\mathrm{z}$ ukształtowania terenu, choć ma to istotne znaczenie jedynie w obszarach górskich i tam standardowo bada się je i uwzględnia jako korektę w późniejszych obliczeniach wieku (Dunai 2010).

Na etapie obliczania wieku ekspozycji możliwe jest zastosowanie poprawek uwzględniających m.in. pokrycie głazu warstwą osadów, śniegu czy osłonięcie drzewami lub też postglacjalną erozję jego powierzchni, jednak każda poprawka uwzględniona w kalkulacjach wpływa na zwiększenie uzyskanego przedziału niepewności (Dunai 2010). Dodatkowo na obszarach, gdzie od dawna ma miejsce działalność człowieka, trzeba uwzględnić możliwość jego wpływów poprzez przemieszczanie, wykopywanie i ustawianie głazów (Graf $i$ in. 2007; Górska-Zabielska 2015), co często skutkuje odrzuceniem wielu eratyków jako nieprzydatnych do uzyskania wiarygodnego czasu deglacjacji. Dlatego też staranna selekcja eratyków przed przystąpieniem do poboru próbek jest kluczowa z punktu widzenia jakości prowadzonych badań.

\section{Obszar badań}

Poszukiwaniami eratyków optymalnych do datowania wieku ekspozycji metodą TCN objęto środkową i wschodnią część Pomorza (rys. 2). W ujęciu fizycznogeograficznym Kondrackiego (2002) analizowany obszar obejmuje: Pobrzeże Koszalińskie, Pobrzeże Gdańskie, Pojezierze Iławskie, Dolinę Dolnej Wisły, zachodnią część Pojezierza Chełmińsko-Dobrzyńskiego oraz wschodnią część Pojezierza Południowopomorskego i Pojezierza Zachodniopomorskiego. Tak zdefiniowany geograficznie obszar mieści się pomiędzy regionami, w których metoda izotopów kosmogenicznych była już stosowana do datowania wieku ekspozycji eratyków (Rinterknecht i in. 2005; Dzierżek, Zreda 2007). Wyniki uzyskane przez Rinterknechta i in. (2005) oraz Dzierżka i Zredę (2007) dostarczyły cennych danych odnośnie wieku maksymalnego zasięgu lądolodu fazy pomorskiej oraz początków recesji lądolodu tej fazy w północnej Polsce, choć nie są one zupełnie zgodne - 15,0 ka wg Rinterknechta i in. (2005) oraz 19,7 ka wg Dzieżka i Zredy (2007). Główną motywacją przy wyborze obszaru badań była więc możliwość wytypowania nowych, odpowiednich do datowania głazów narzutowych oraz perspektywa uzupełnienia i uszczegółowienia chronologii recesji ostatniego lądolodu skandynawskiego w północnej Polsce (rys. 2A).

Powierzchniowa budowa geologiczna oraz rzeźba terenu obszaru badań zostały ukształtowane w przeważającej mierze w schyłkowej części zlodowacenia wisły (Marks i in. 2006). Dominują tu plejstoceńskie gliny lodowcowe (lokalnie także piaski i żwiry lodowcowe), budujące powierzchnie wysoczyzn morenowych oraz piaski i żwiry wodnolodowcowe, tworzące rozlegke sandry (rys. 2B). Biorąc pod uwagę rozwój rzeźby oraz związane z nim rozmieszczenie osadów powierzchniowych, analizowany obszar można podzielić na pięć stref. Pierwszą z nich stanowią wysoczyzny o umiarkowanych deniwelacjach, powstałe podczas recesji lądolodu w fazie poznańskiej. Rozpościerają się one od południowych krańców obszaru badań do strefy zasięgu lądolodu w fazie pomorskiej. Strefa ta odpowiada południowej części Pojezierza Południowopomorskiego oraz Pojezierzu Chełmińsko-Dobrzyńskiemu (rys. 2B). Druga strefa obejmuje relatywnie płaskie, rozległe powierzchnie sandrowe, 


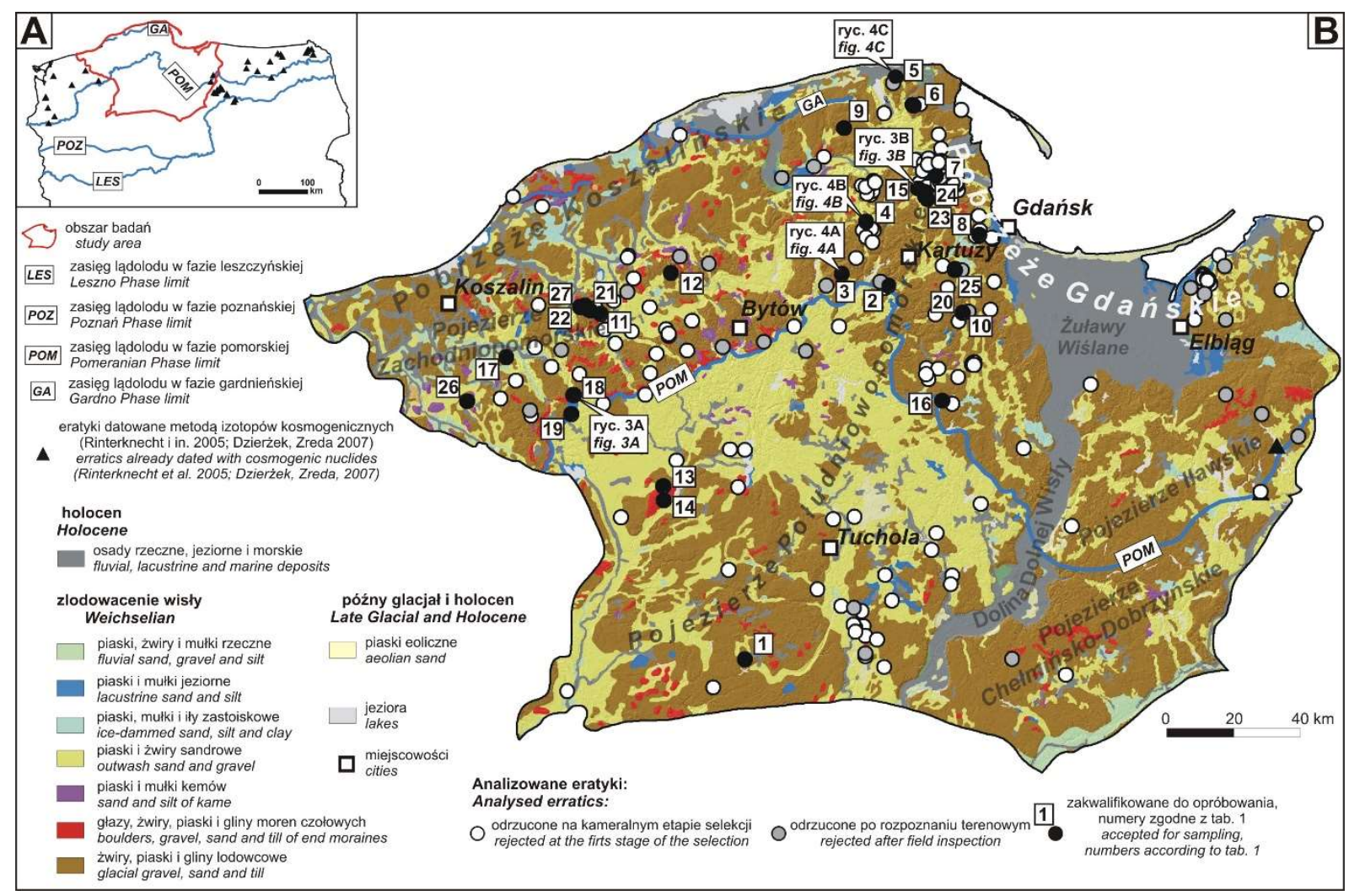

Rys. 2. Obszar badań oraz lokalizacja głazów narzutowych

A - obszar badań na tle głównych zasięgów ostatniego lądolodu skandynawskiego w Polsce (Kozarski 1995; Marks i in. 2006) i rozmieszczenia głazów narzutowych datowanych w przeszłości metodą TCN; B - powierzchniowe utwory geologiczne obszaru badań (Marks i in. 2006) oraz lokalizacja analizowanych eratyków

\section{Study area and the localisation of erratics}

A - study area against the main ice margin limits of the last Scandinavian Ice Sheet in Poland (Kozarski 1995; Marks et al. 2006) and erratics already dated with TCN; B - surface geology of the study area (Marks et al. 2006) and localisation of the analysed erratics

ciągnące się na południe od linii zasięgu lądolodu $\mathrm{w}$ fazie pomorskiej, w tym sandry dolinne rozcinające wysoczyzny strefy pierwszej (rys. 2B). Wzdłuż linii zasięgu lądolodu fazy pomorskiej występuje silnie urzeźbiona strefa trzecia - tzw. garb pojezierny (Mojski 2005) zbudowany zazwyczaj ze skrajnie źle wysortowanego materiału żwirowo-piaszczystego i glin lodowcowych. $\mathrm{W}$ tej strefie deniwelacje są największe, co wynika $\mathrm{z}$ obecności nie tylko wzgórz morenowych o znacznych wysokościach, ale także głębokich rozcięć o charakterze rynien polodowcowych (Gołębiewski i in. 2005). Odpowiada ona wschodniej części Pojezierza Zachodniopomorskiego, północnej części Pojezierza Południowopomorskiego oraz Pojezierzu Iławskiemu wraz z położoną na północny wschód od Elbląga Wysoczyzną Elbląską (rys. 2B). Strefę czwartą stanowią obszary odsłonięte w schyłkowych etapach deglacjacji północnej Polski (w tym w fazie gardnieńskiej) - na ogół dość płaskie, choć lokalne duże deniwelacje mogą tu być związane $\mathrm{z}$ obecnością stref czołowomorenowych (Jasiewicz 2005), bądź rozcięć erozyjnych, w tym obniżeń pradolinnych (Woźniak 2014). Odpowiada ona Pobrzeżu Koszalińskiemu oraz zachodniej części Pobrzeża Gdańskiego (rys. 2B).Wszystkie wymienione powyżej strefy rozcina strefa piąta - południkowo biegnąca dolina Wisły i delta tej rzeki (Żuławy Wiślane).

Znacznego nagromadzenia materiału eratycznego na powierzchni terenu należy spodziewać się w strefach występowania skrajnie źle wysortowanych utworów lodowcowych, tj. glin, żwirów i piasków zwałowych z głazami. Obszary o urozmaiconej rzeźbie polodowcowej położone na zapleczu zasięgu lądolodu fazy pomorskiej charakteryzują się największym zagęszczeniem dużych głazów narzutowych w Polsce (Czernicka-Chodkowska 1977, 1983). Na analizowanym obszarze należą do nich strefa trzecia i czwarta (rys. 2B). Równocześnie można zakładać, że transformacja bogato 
urzeźbionego terenu już po deglacjacji (denudacja i erozja) mogła przyczynić się do zmiany położenia i przykrycia głazów. Stąd też najprawdopodobniej spośród dużej liczby obiektów występujących na tych obszarach, znaczna część wymaga wykluczenia, ponieważ czas ekspozycji ich powierzchni nie pokrywa się z czasem, jaki upłynął od deglacjacji. Z drugiej strony obszary deltowe Wisły oraz jej dolina (strefa piąta) pozbawione są dużych odsłoniętych eratyków.

\section{Sposób selekcji}

Źródłem informacji o potencjalnych obiektach przydatnych do datowania TCN na Pomorzu były przede wszystkim spisy pomników przyrody udostępnione przez Regionalne Dyrekcje Ochrony Środowiska (RDOŚ) w Gdańsku i Szczecinie. Zawierają one współrzędne geograficzne chronionych głazów narzutowych, zapisy o rozmiarach eratyków (obwód i wysokość) oraz o rodzaju budującej je skały. Dodatkowo także można w nich odnaleźć informacje, np. dotyczące wpływów antropogenicznych (wzmianki o wykopaniu i/lub ustawieniu przez człowieka). Oprócz spisów RDOŚ autorzy korzystali również z dostępnego od lat katalogu głazów narzutowych (CzernickaChodkowska 1977, 1983) i innych publikacji (Alexandrowicz i in. 1975; Szarzyńska, Ziółkowski 2012; Woźniak i in. 2015), jak też z prac licencjackich i magisterskich (Binkowski 2013; Ilewicz, Kobiela 2014; Sauter 2015) oraz informacji uzyskanych z leśnictw, urzędów gmin i parków krajobrazowych.

Na podstawie zebranych danych utworzono bazę GIS wielkich eratyków na środkowym i wschodnim Pomorzu, zawierającą informacje o ich lokalizacji, wymiarach i litologii. Następnie warstwę z punktami (plik shape) nałożono na cyfrowy model wysokościowy oraz Szczegółową mapę geologiczną Polski (SMGP). Cyfrowe dane wysokościowe pochodziły $\mathrm{z}$ modelu DTED 2 utworzonego na podstawie wektoryzacji poziomic z map topograficznych w skali 1:50 000 i udostępnianego przez Oddział Geodezji i Kartografii Sztabu Generalnego Wojska Polskiego (Gotlib, Olszewski 2006). Dane SMGP zostały zaczerpnięte z geoportalu Centralnej Bazy Danych Geologicznych Państwowego Instytutu Geologicznego - Państwowego Instytutu Badawczego (PIG-PIB).

Pierwszy etap selekcji polegał na wyborze największych eratyków (o obwodzie $\geq 5 \mathrm{~m}$ i wysokości $\geq 0,5 \mathrm{~m}$ ), zlokalizowanych na wyso- czyznach morenowych i w wybranych częściach stref marginalnych ostatniego lądolodu skandynawskiego (moreny czołowe, proksymalne części sandrów), jako tych, których wiek ekspozycji będzie najlepszym wskaźnikiem początków deglacjacji badanego obszaru. Minimalne graniczne wymiary eratyków przyjęto arbitralnie po analizie informacji na temat rozmiarów eratyków zawartych w bazie GIS. Granice te dają minimalną objętość głazu rzędu $0,7 \mathrm{~m}^{3}$, zakładając obwód eratyka w kształcie koła oraz stosując wzór na szacowaną objętość eratyków wg Schulza (2003): $\mathrm{V}=0,523 \cdot \mathrm{a} \cdot \mathrm{b} \cdot \mathrm{c}$, gdzie ,a” jest długością, „b” szerokością, a ,c” wysokością eratyka. W obszarach niżowych, pokrytych w przeszłości przez plejstoceńskie lądolody, zazwyczaj do datowania wieku ekspozycji metodą TCN wybiera się eratyki o objętości $\geq 1 \mathrm{~m}^{3}$ (Heine i in. 2009; Houmark-Nielsen $i$ in. 2012; Rinterknecht $i$ in. 2012, 2014), jednak na pierwszym etapie proponowanej kwalifikacji szacowana wartość $0,7 \mathrm{~m}^{3}$ jest zdaniem autorów wystarczająca do wytypowania eratyków „wartych” odnalezienia w terenie. Tak wyselekcjonowane narzutniaki były przedmiotem weryfikacji terenowej, która stanowiła drugi etap selekcji eratyków najbardziej odpowiednich do datowania wieku ekspozycji metodą TCN.

Prace terenowe zostały wykonane w 2015 i 2016 roku. Polegały na odnalezieniu głazów oraz określeniu (lub weryfikacji) ich współrzędnych za pomocą odbiornika GPS. Zmierzono maksymalny obwód oraz wysokość narzutniaków. Określono lub zweryfikowano ich typ petrograficzny oraz lokalizację geomorfologiczną (rodzaj form terenu, w obrębie których są one położone). Szczególną uwagę zwrócono na cechy wskazujące na położenie eratyków in situ - osadzenie w gruncie, zwietrzenie powierzchni skały, świadczące o jej długiej ekspozycji na czynniki atmosferyczne (fot. 1A), czy też rysy i zadziory lodowcowe oraz wygładzone powierzchnie, świadczące o działalności erozyjnej lądolodu (fot. 1B).

\section{Rezultaty badań terenowych}

Utworzona baza GIS obiektów zlokalizowanych na badanym obszarze liczy 254 głazy. Ich rozmieszczenie wykazuje największą koncentrację w pasie Pojezierza Zachodniopomorskiego oraz północnej części Pojezierza Południowopomorskiego (rys. 2), co ma najprawdopodobniej związek z przebiegiem stref marginalnych ostatniego lądolodu oraz ekshumacją gruboziarnistego 

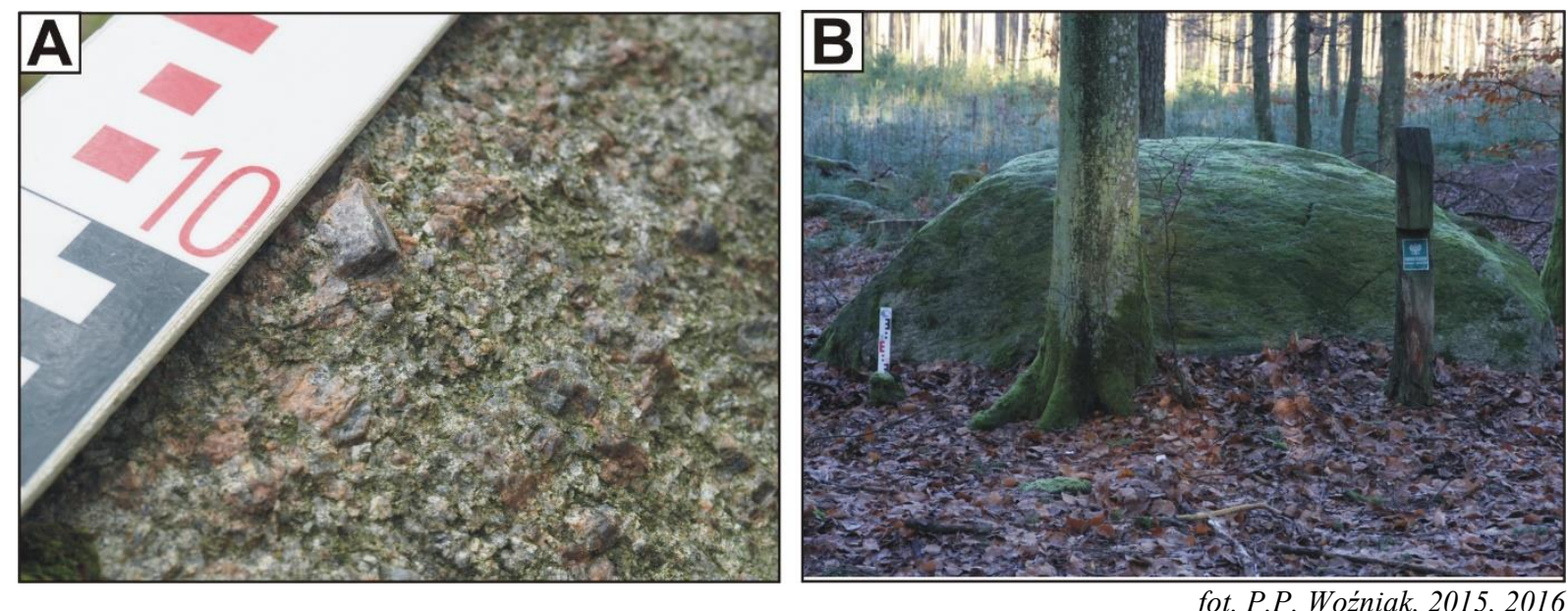

Fot. 1. Cechy mogące świadczyć o położeniu eratyków in situ

A - zwietrzała powierzchnia granitoidu z wystającymi kryształami skaleni;

$\mathrm{B}$ - granitognejs z górną powierzchnią ogładzoną glacjalnie

Features indicating in-situ location of erratic

A - weathered surface of granitoid with protruding crystals of feldspar;

B - graninic gneiss with glacially polished upper surface

materiału okruchowego $\mathrm{w}$ rezultacie denudacji i erozji postglacjalnej obszarów o znacznych deniwelacjach. W źródłach, na podstawie których skonstruowano bazę (patrz poprzedni rozdział), podano obwód dla 244 eratyków (od $2 \mathrm{~m}$ do 50 m), zaś wysokość tylko dla $87 \mathrm{z}$ nich (od $0,5 \mathrm{~m}$ do 3,8 m). Litologia większości eratyków nie została określona. Wśród tych, dla których informacja ta była znana (47 głazów), dominują granitoidy (28) oraz gnejsy (8) i granitognejsy (6), inne skały są reprezentowane przez pojedyncze obiekty. Nieco ponad połowa narzutniaków (129 eratyki) jest zlokalizowana w obrębie wysoczyzn lub wzgórz morenowych, prawie 25\% (63 głazy) - w dolinach rzecznych, a 16\% (40 eratyków) - na sandrach. Znacznie mniej głazów (13 obiektów) leży w rynnach polodowcowych, na terasach kemowych i kemach (7) oraz na morskiej plaży (2).

Analiza bazy narzutniaków pod względem ich rozmiaru oraz lokalizacji geomorfologicznej doprowadziła do wytypowania 57 głazów potencjalnie przydatnych do dalszych badań. Wyeliminowano głazy o obwodzie mniejszym niż $5 \mathrm{~m}$ oraz położone w obrębie form erozyjnych (gdyż najprawdopodobniej zostały ekshumowane z osadów) i na rozległych powierzchniach sandrowych (gdzie również istnieje ryzyko wypreparowania eratyków $\mathrm{z}$ osadów w rezultacie wysokoenergetycznych przepływów wód roztopowych), jak również głazy leżące na plaży (niewątpliwie pochodzące z klifów) oraz przemieszczone lub ustawione przez człowieka. Kryterium wysokości $(\geq 0,5 \mathrm{~m})$ spełniały wszystkie eratyki, dla których podana była ta wartość w bazie GIS. Wytypowane głazy są więc eratykami znacznych rozmiarów, położonymi w obrębie wysoczyzn morenowych i akumulacyjnych form marginalnych (szare i czarne punkty na rys. 2). Ich średni obwód wynosi $12 \mathrm{~m}$, a średnia wysokość $1,6 \mathrm{~m}$. Analiza doprowadziła do znacznej redukcji zbioru eratyków (odrzucono 77,6\% obiektów).

Generalny obraz rozmieszczenia eratyków po pierwszym etapie selekcji nie uległ znacznym modyfikacjom - największa koncentracja głazów wciąż występuje w pasie Pojezierza Zachodnopomorskiego i północnej części Pojezierza Południowopomorskiego pomiędzy Koszalinem, Bytowem i Gdańskiem. Jednakże w obszarach takich jak Wysoczyzna Elbląska na północny wschód od Elbląga, czy też południowa część Pojezierza Południowopomorskiego w okolicy Tucholi redukcja zbioru eratyków była szczególnie duża (odpowiednio 83,3\% i 93,1\%). Głównym powodem wykluczenia niemal wszystkich eratyków na Wysoczyźnie Elbląskiej była ich lokalizacja w obrębie rozcięć erozyjnych, powszechnie występujących w brzeżnej części wysoczyzny (Makowska 1999), zaś w okolicach Tucholi przyczyną było położenie głazów na rozległych sandrach (rys. 2).

Drugi etap selekcji (weryfikacja terenowa) spowodował odrzucenie 30 z 57 eratyków. Najwięcej głazów pominięto z powodu niepożądanej lokalizacji morfologicznej (narzutniaki położone na krótkich stokach lub w dnach dolinek denudacyjnych - 14 głazów), w przypadku sześciu 
stwierdzono ingerencję człowieka (głazy wykopane lub ustawione), siedem głazów zostało rozpoznanych jako zbyt niskie w stosunku do deniwelacji w najbliższym otoczeniu, zaś trzech nie udało się odnaleźć w terenie (prawdopodobnie zostały wywiezione w inne miejsce lub zniszczone). W rezultacie wyselekcjonowano grupę 27 głazów, spełniających założone kryteria przydatności do datowania wieku ekspozycji metodą TCN oraz interpretacji wieku fazy pomorskiej stadiału głównego zlodowacenia wisły (tab. 1). Są to głazy narzutowe znacznych rozmiarów, położone in situ na powierzchni polodowcowych wysoczyzn i akumulacyjnych form marginalnych - na morenach czołowych lub proksymalnych częściach sandrów (czarne punkty na rys. 2). W grupie tej dominują eratyki zbudowane $\mathrm{z}$ granitoidów (15 głazów), gnejsów (6) oraz granitognejsów (5). Jedynie jeden głaz (największy w Polsce - „Trygław”) jest zbudowany z migmatytu. Ich obwód wynosi od $6,1 \mathrm{~m}$ do $50,0 \mathrm{~m}$, a widoczna powyżej powierzchni terenu wysokość waha się od $0,9 \mathrm{~m}$ do $3,8 \mathrm{~m}$. Szacowana objętość analizowanych narzutniaków wynosi od $2,1 \mathrm{~m}^{3}$ do $253,2 \mathrm{~m}^{3}$; większość $\mathrm{z}$ nich (19) mieści się w przedziale do $20 \mathrm{~m}^{3}$ (tab. 1). Największy eratyk (głaz „Trygław”) znacznie odstaje wielkością od pozostałych. Prawie wszystkie, z wyjątkiem jednego, są osadzone w gruncie. Większość narzutniaków posiada wyraźne ślady erozyjnej działalności lądolodu (spłaszczone i ogładzone powierzchnie, ewentualnie rysy lodowcowe), ale często również ich powierzchnia wykazuje cechy długotrwałego oddziaływania wietrzenia (chropowatość, ślady łuszczenia). Na powierzchni badanych eratyków nie zaobserwowano wprawdzie wyraźnych śladów świadczących o działalności korazyjnej wiatru w strefie peryglacjalnej (ostre krawędzie, żłobki i zadziory korazyjne), jednak na przedpolu odstępującego lądolodu głazy narzutowe były zapewne narażone na oddziaływanie tego rodzaju procesów (por. Antczak-Górka 2010).

Tabela 1

Charakterystyka głazów narzutowych na środkowym i wschodnim Pomorzu zakwalifikowanych do datowania ekspozycyjnego metodą TCN

Characteristics of the erratic boulders in the middle and eastern Pomerania selected as a suitable for exposure dating with TCN

\begin{tabular}{|c|c|c|c|c|c|c|c|c|}
\hline$\dot{z} \dot{z}^{0}$ & 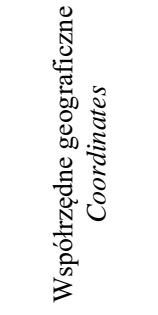 & 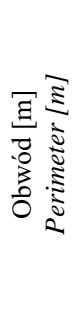 & 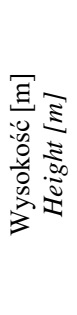 & 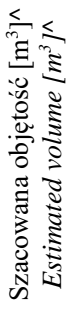 & \begin{tabular}{l}
$\frac{\pi}{3} \cong$ \\
\multirow{3}{*}{} \\
Z
\end{tabular} & 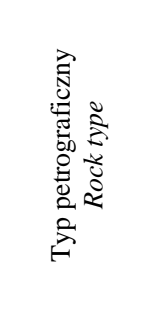 & 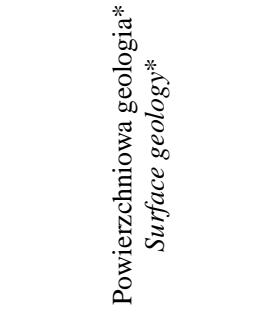 & 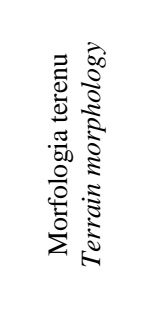 \\
\hline 1 & $\begin{array}{c}53^{\circ} 16^{\prime} 56,1^{\prime \prime} ; \\
17^{\circ} 30^{\prime} 26,5^{\prime \prime}\end{array}$ & 8,9 & 1,2 & 4,2 & - & granitoid & glina lodowcowa & wysoczyzna \\
\hline 2 & $\begin{array}{l}54^{\circ} 15^{\prime} 32,0^{\prime \prime} ; \\
18^{\circ} 06^{\prime} 16,2^{\prime \prime}\end{array}$ & 6,1 & 1,5 & 8,9 & Królewski Kamień & gnejs & glina lodowcowa & wzgórze \\
\hline 3 & $\begin{array}{l}54^{\circ} 17^{\prime} 17,7^{\prime \prime} ; \\
17^{\circ} 54^{\prime} 03,6^{\prime \prime}\end{array}$ & 13,7 & 2,0 & 16,9 & Łosienicki Kamień & granitoid & glina lodowcowa & wzgórze \\
\hline 4 & $\begin{array}{c}54^{\circ} 25^{\prime} 27,1^{\prime \prime} ; \\
18^{\circ} 00^{\prime} 22,9^{\prime \prime} \\
\end{array}$ & 17,6 & 3,1 & 58,4 & $\begin{array}{c}\text { Diabelski / } \\
\text { Pęknięty Kamień }\end{array}$ & granitognejs & glina lodowcowa & wytopisko \\
\hline 5 & $\begin{array}{c}54^{\circ} 48^{\prime} 00,5^{\prime \prime} ; \\
18^{\circ} 07^{\prime} 40,1^{\prime \prime}\end{array}$ & 20,5 & 2,7 & 51,3 & $\begin{array}{c}\text { Stojący / } \\
\text { Diabelski Kamień }\end{array}$ & granitoid & glina lodowcowa & wysoczyzna \\
\hline 6 & $\begin{array}{l}54^{\circ} 43^{\prime} 9,4^{\prime \prime} \\
18^{\circ} 12^{\prime} 37,7^{\prime \prime}\end{array}$ & 13,4 & 2,4 & 23,2 & Diabelski Kamień & gnejs & glina lodowcowa & wzgórze \\
\hline 7 & $\begin{array}{l}54^{\circ} 32^{\prime} 47,5^{\prime \prime} ; \\
18^{\circ} 18^{\prime} 52,7^{\prime \prime} \\
\end{array}$ & 12,5 & 1,8 & 14,8 & - & granitoid & glina lodowcowa & wysoczyzna \\
\hline 8 & $\begin{array}{c}54^{\circ} 23^{\prime} 35,6^{\prime \prime} ; \\
18^{\circ} 30^{\prime} 36,0^{\prime \prime}\end{array}$ & 12,5 & 2,7 & 23,7 & Diabelski Kamień & granitoid & glina lodowcowa & wysoczyzna \\
\hline 9 & $\begin{array}{l}54^{\circ} 39^{\prime} 59,0^{\prime \prime} \\
17^{\circ} 54^{\prime} 03,8^{\prime \prime}\end{array}$ & 16,0 & 1,7 & 22,4 & - & granitognejs & deluwium & wysoczyzna \\
\hline 10 & $\begin{array}{l}54^{\circ} 11^{\prime} 27,6^{\prime \prime} ; \\
18^{\circ} 26^{\prime} 22,4^{\prime \prime}\end{array}$ & 11,0 & 1,4 & 6,7 & - & granitoid & piasek i żwir sandrowy & sandr \\
\hline 11 & $\begin{array}{c}54^{\circ} 10^{\prime} 14,0^{\prime \prime} ; \\
16^{\circ} 50^{\prime} 03,4^{\prime \prime}\end{array}$ & 13,0 & 1,7 & 11,7 & - & granitognejs & glina lodowcowa & wysoczyzna \\
\hline
\end{tabular}


Analiza przydatności eratyków Pomorza w badaniach chronologii recesji ostatniego lądolodu skandynawskiego

\begin{tabular}{|c|c|c|c|c|c|c|c|c|}
\hline 12 & $\begin{array}{l}54^{\circ} 16^{\prime} 56,1^{\prime \prime} ; \\
17^{\circ} 08^{\prime} 28,3^{\prime \prime}\end{array}$ & 12,5 & 1,4 & 11,8 & Głaz Trzech Panów & granitoid & glina lodowcowa & wysoczyzna \\
\hline 13 & $\begin{array}{l}53^{\circ} 43^{\prime} 37,7^{\prime \prime} \\
17^{\circ} 08^{\prime} 03,2^{\prime \prime}\end{array}$ & 14,6 & 2,1 & 18,5 & - & granitoid & glina lodowcowa & wysoczyzna \\
\hline 14 & $\begin{array}{l}53^{\circ} 41^{\prime} 25,1^{\prime \prime} ; \\
17^{\circ} 08^{\prime} 13,8^{\prime \prime}\end{array}$ & 20,5 & 1,9 & 41,0 & - & gnejs & piasek i żwir lodowcowy & wysoczyzna \\
\hline 15 & $\begin{array}{l}54^{\circ} 30^{\prime} 45,2^{\prime \prime} ; \\
18^{\circ} 14^{\prime} 06,7^{\prime \prime}\end{array}$ & 10,0 & 0,9 & 4,0 & Obły Kamień & granitognejs & piasek i żwir lodowcowy & wzgórze \\
\hline 16 & $\begin{array}{l}53^{\circ} 57^{\prime} 42,2^{\prime \prime} ; \\
18^{\circ} 21^{\prime} 02,0^{\prime \prime}\end{array}$ & 14,8 & 2,5 & 22,0 & - & gnejs & piasek i żwir lodowcowy & wytopisko \\
\hline 17 & $\begin{array}{l}54^{\circ} 02^{\prime} 58,6^{\prime \prime} ; \\
16^{\circ} 25^{\prime} 40,0^{\prime \prime}\end{array}$ & 10,5 & 1,6 & 8,6 & - & granitoid & glina lodowcowa & wysoczyzna \\
\hline 18 & $\begin{array}{l}53^{\circ} 57^{\prime} 27,2^{\prime \prime} ; \\
16^{\circ} 43 ' 34,2^{\prime \prime}\end{array}$ & 6,6 & 1,3 & 2,5 & - & granitoid & piasek i żwir lodowcowy & wzgórze \\
\hline 19 & $\begin{array}{l}53^{\circ} 54^{\prime} 26,0^{\prime \prime} ; \\
16^{\circ} 43^{\prime} 11,8^{\prime \prime}\end{array}$ & 10,8 & 1,0 & 4,6 & - & gnejs & torf & wytopisko \\
\hline 20 & $\begin{array}{l}54^{\circ} 11^{\prime} 27,6^{\prime \prime} \\
18^{\circ} 26^{\prime} 22,4^{\prime \prime}\end{array}$ & 12,5 & 1,7 & 12,4 & - & granitoid & piasek i żwir sandrowy & sandr \\
\hline 21 & $\begin{array}{l}54^{\circ} 10^{\prime} 37,3^{\prime \prime} ; \\
16^{\circ} 47^{\prime} 19,1^{\prime \prime}\end{array}$ & 8,0 & 1,3 & 2,1 & - & granitoid & torf & wytopisko \\
\hline 22 & $\begin{array}{l}54^{\circ} 11^{\prime} 27,4^{\prime \prime} ; \\
16^{\circ} 45^{\prime} 59,1^{\prime \prime}\end{array}$ & 7,4 & 1,3 & 3,2 & - & granitoid & piasek i żwir lodowcowy & wysoczyzna \\
\hline 23 & $\begin{array}{l}54^{\circ} 29^{\prime} 27,7^{\prime \prime} \\
18^{\circ} 16^{\prime} 05,4^{\prime \prime}\end{array}$ & 10,1 & 1,7 & 5,8 & - & gnejs & piasek i żwir sandrowy & sandr \\
\hline 24 & $\begin{array}{l}54^{\circ} 30^{\prime} 13,8^{\prime \prime} ; \\
18^{\circ} 16^{\prime} 05,1^{\prime \prime}\end{array}$ & 7,8 & 1,4 & 4,0 & Lipowy Kamień & granitoid & piasek i żwir lodowcowy & wzgórze \\
\hline 25 & $\begin{array}{l}54^{\circ} 18^{\prime} 02,3^{\prime \prime} ; \\
18^{\circ} 24^{\prime} 13,6^{\prime \prime}\end{array}$ & 15,0 & 1,4 & 12,9 & - & granitoid & glina lodowcowa & wysoczyzna \\
\hline 26 & $\begin{array}{l}53^{\circ} 55^{\prime} 53,7^{\prime \prime} ; \\
16^{\circ} 15^{\prime} 39,8^{\prime \prime}\end{array}$ & 50,0 & 3,8 & 253,2 & Trygław & migmatyt & piasek i żwir lodowcowy & wysoczyzna \\
\hline 27 & $\begin{array}{l}54^{\circ} 11^{\prime} 09,7^{\prime \prime} ; \\
16^{\circ} 44^{\prime} 43,0^{\prime \prime}\end{array}$ & 8,0 & 1,5 & 5,7 & & granitognejs & piasek i żwir lodowcowy & wysoczyzna \\
\hline
\end{tabular}

^ Objętość eratyków obliczono zgodnie ze wzorem zaproponowanym przez Schulza (2003): V =0,523·a·b·c, gdzie a, b i c to kolejno: długość, szerokość i wysokość głazu. Tak obliczona objętość głazów jest jedynie przybliżeniem objętości rzeczywistej z uwagi na fakt, iż wszystkie głazy charakteryzują się nieregularnym kształtem brył i w prawie wszystkich przypadkach jakaś ich część znajduje się pod powierzchnią gruntu

* Wg danych Szczegółowej mapy geologicznej Polski (SMGP)

Przełom XIX i XX wieku oraz czasy przedwojenne to okres intensywnej ingerencji człowieka w rozmieszczenie i stan zachowania głazów narzutowych na Pomorzu. Były wówczas istotnym materiałem budowlanym dróg bitych oraz zabudowań. A z uwagi na rozwój środków technicznych (dźwigi, koparki), pozwalających na przemieszczanie głazów znacznych rozmiarów, często zmieniały swoje położenie. Stąd ważnym elementem selekcji głazów pod kątem ich przydatności do datowań kosmogenicznych jest porównanie stanu obecnego $\mathrm{z}$ tym zarejestrowanym na archiwalnych, możliwie najstarszych fotografiach. Część z wyselekcjonowanych głazów (7 narzutniaków) była przedmiotem badań pruskiego geologa Hermanna (1911). Sięgnięcie do opublikowanych przez niego fotografii dokumentujących stan głazów w początkach XX wieku (fot. 2), prowadzi do wniosku, że wyselekcjonowane obiekty, pomimo widocznych zmian pokrycia roślinnego w swoim otoczeniu, zachowały się $\mathrm{w}$ niemal nienaruszonym stanie.
Z głazów, które przeszły proces selekcji przedstawiony $\mathrm{w}$ artykule, zostały pobrane próbki do oznaczenia zawartości w kwarcu izotopu kosmogenicznego ${ }^{10} \mathrm{Be}$. Wyniki tych analiz umożliwią określenie wieku ekspozycji eratyków, a w konsekwencji odtworzenie chronologii ostatniej deglacjacji środkowego i wschodniego Pomorza.

\section{Podsumowanie i wnioski}

1. Systematyczna kwalifikacja wielkich eratyków Pomorza wsparta szczegółową analizą materiałów źródłowych, zastosowaniem oprogramowania GIS oraz informacjami uzyskanymi w trakcie prac terenowych umożliwiła wyselekcjonowanie narzutniaków znacznych rozmiarów zlokalizowanych in situ na powierzchni wysoczyzn morenowych oraz akumulacyjnych form marginalnych. 

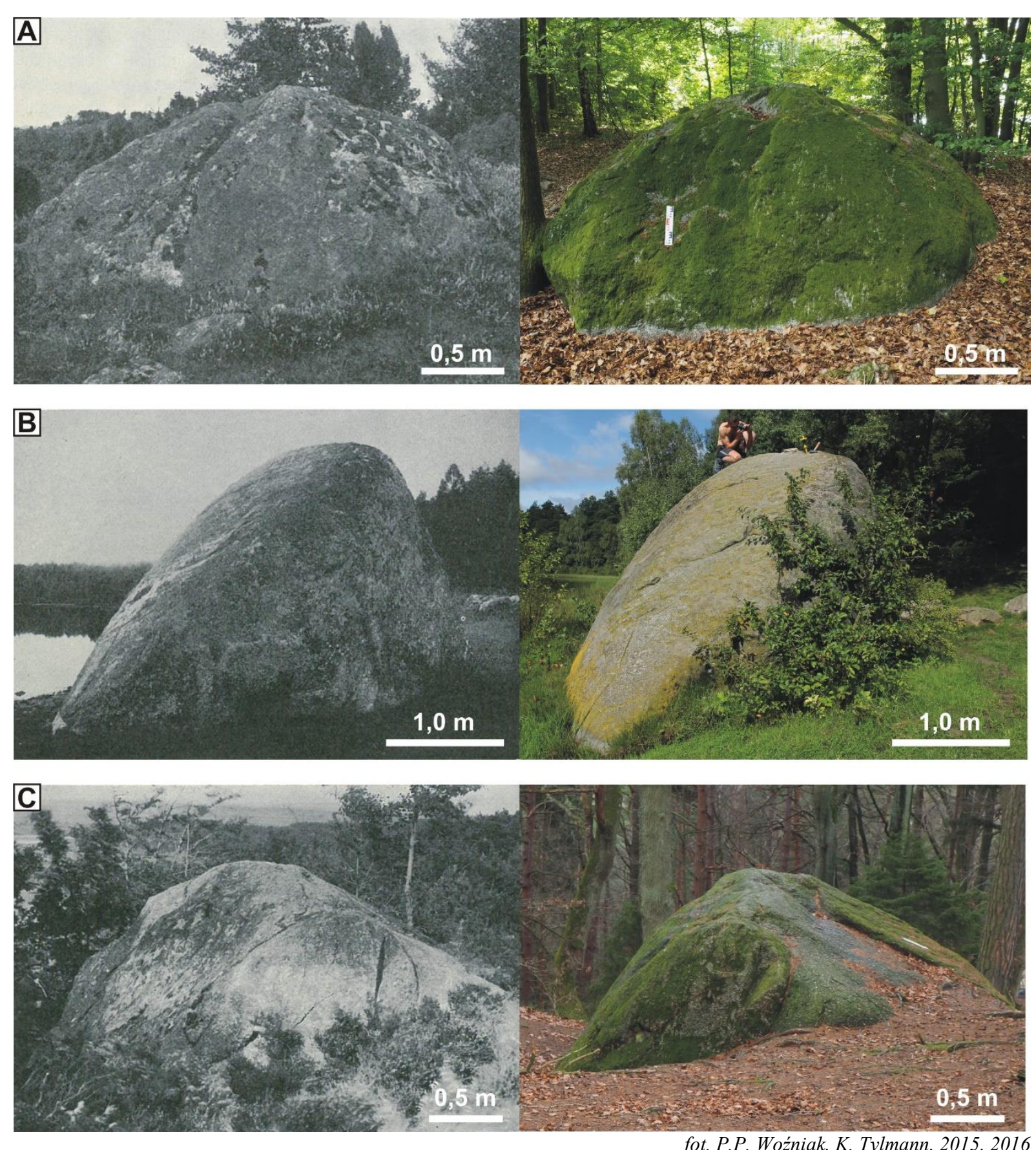

Fot. 2. Przykłady eratyków zakwalifikowanych do datowania ekspozycyjnego metodą TCN.

Po lewej stronie przedstawiono fotografie archiwalne z początku XX wieku zaczerpnięte z pracy Hermanna (1911), po prawej stronie fotografie współczesne

A - „,Łosienicki Kamień” na skraju wzgórza morenowego w okolicach Kartuz (tab. 1, nr 3); B - „Pęknięty Kamień” (zwany też „Diabelskim Kamieniem”) nad Jeziorem Kamiennym w okolicy Kartuz (tab. 1, nr 4); C - „Diabelski Kamień”, zwany też „Stojącym” (tab. 1, nr 5) - jeden z największych głazów narzutowych na Pomorzu, położony na skraju wysoczyzny morenowej w północnej części Pobrzeża Gdańskiego

Examples of erratics selected as a suitable for exposure dating with TCN.

On the left side there are archival photographs from the beginning of XX century according to Hermann (1911), and on the right side there are present day photographs

A - "Losienicki Stone" on the edge of the moraine hill in the vicinity of Kartuzy (Tab. 1, no 3); B - "Broken Stone" (named also "Devil's Stone") at the Kamienne Lake in the vicinity of Kartuzy (Tab. 1, no 4); C - "Devil`s Stone", named also "Standing" (Tab. 1, no 5) - one of the biggest erratic boulder in Pomerania, located on the edge of a moraine plateau in the northern part of the Gdańsk Seashore 
2. Mimo dużej liczby obiektów w podstawowej bazie danych (254 głazy) w wyniku kameralnego etapu selekcji odrzucono aż 77,6\% narzutniaków. Zadecydowało o tym bogate urzeźbienia analizowanego terenu - wiele głazów leżało na stoku i/lub zostało odsłoniętych w wyniku procesów erozyjnych już po deglacjacji, położenie na rozległych obszarach sandrowych oraz zbyt mały rozmiar. Uzyskano w ten sposób zbiór 57 głazów potencjalnie przydatnych do następnego etapu kwalifikacji.

3. Podczas weryfikacji terenowej wytypowanych głazów odrzucono, ze względu na niepożądaną lokalizację morfologiczną (narzutniaki położone na krótkich stokach lub w dnach dolinek denudacyjnych), ingerencję człowieka (głazy wykopane lub ustawione), zbyt małą wysokość lub niemożność odnalezienia w terenie, kolejnych 30 eratyków.

4. Ostatecznie 27 wytypowanych głazów uznano za obiekty przydatne do datowania wieku ekspozycji metodą TCN. Większość z nich położona jest w obrębie wysoczyzn i wzgórz morenowych północnej części Pojezierza Pomorskiego oraz w pasie Pojezierza Zachodniopomorskiego choć to właśnie na tych obszarach kwalifikacja wyeliminowała najwięcej obiektów. Są to równocześnie tereny kluczowe dla tworzenia chronologii deglacjacji, ponieważ to przez nie przebiega linia zasięgu lądolodu $\mathrm{w}$ fazie pomorskiej ostatniego zlodowacenia.

5. Znaczna redukcja obiektów na poszczególnych etapach kwalifikacji pokazuje wagę każdego z nich. Dobrze zaplanowana filtracja obiektów na etapie kameralnym (odrzucono 197 z 254 narzutniaków, czyli zakwalifikowano jedynie nieco ponad 20\%) pozwoliła znacznie ograniczyć nakłady ponoszone podczas weryfikacji terenowej (odrzucono tylko 30 z 57 głazów). Z kolei drugi etap pozwolił skonfrontować rozmiary eratyka $\mathrm{z}$ morfologią terenu w jego najbliższym otoczeniu, określić wpływy lokalnych czynników ograniczających dopływ wtórnego promieniowania kosmicznego do skały oraz wykryć ewentualne świadectwa przemieszczania głazu lub ingerencji $\mathrm{w}$ jego powierzchnię.

6. Głazy z ostatecznie wyselekcjonowanej grupy uznano za przydatne do poboru próbek i datowania wieku ekspozycji metodą TCN, służącego oszacowaniu wieku ostatniej deglacjacji badanego obszaru. Uzyskane wyniki pozwolą na uzupełnienie i uszczegółowienie danych na temat chronologii recesji ostatniego lądolodu skandynawskiego dla obszaru północnej Polski.

\section{Podziękowania}

Autorzy składają podziękowania Regionalnym Dyrekcjom Ochrony Środowiska w Gdańsku i Szczecinie za przychylność i pomoc w zebraniu informacji na temat wielkich głazów narzutowych. Dziękujemy również Mateuszowi Binkowskiemu, Piotrowi K. Ilewiczowi, Marcinowi H. Kobieli oraz Michaelowi Sauterowi za udostępnienie wyników prac licencjackich i magisterskich. Wyrazy wdzięczności składamy także pracownikom Lasów Państwowych za nieocenioną pomoc $\mathrm{w}$ terenie podczas poszukiwań eratyków. Wojciechowi Wysocie dziękujemy za inspirację i ciekawe dyskusje a Marii Górskiej-Zabielskiej oraz anonimowemu Recenzentowi za wszelkie uwagi i sugestie, które przyczyniły się do polepszenia jakości artykułu.

Badania były finansowane ze środków grantu Narodowego Centrum Nauki nr 2014/15/D/ST10/04113, grantu UG nr 538-6240-B570-17 oraz działalności statutowej Zakładu Geologii Morza UG.

\section{Literatura}

Agassiz L. 1837. Des glaciers, des moraines, et des blocs erratiques. Verhandlungen der Schweizerischen Naturforschenden Gesellschaft 22: 5-30.

Alexandrowicz Z., Drzał M., Kozłowski S. 1975. Katalog rezerwatów i pomników przyrody nieożywionej w Polsce. Studia Naturae, ser. B 26: 1-298.

Antczak-Górka B. Zróżnicowanie populacji głazów eolizowanych w różnowiekowych strefach peryglacjalnych Polski Zachodniej. Badania Fizjograficzne. Seria A - Geografia Fizyczna (A61): 9-29.

Binkowski M. 2013. Waloryzacja głazów narzutowych Polski północno-środkowej pod kątem zastosowania metody izotopów kosmogenicznych. Maszynopis pracy magisterskiej, Archiwum UMK, Toruń.

Buchholz A. 2000. Die Trilobitenfauna der oberkambrischen Stufen 1-3 in Geschieben von Vorpommern und Mecklenburg (Norddeutschland). Archiv für Geschiebekunde 2(10): 697-776.

Cerling T.E., Craig H. 1994. Cosmogenic ${ }^{3} \mathrm{He}$ production rates from $39^{\circ} \mathrm{N}$ to $46^{\circ} \mathrm{N}$ latitude, western USA and France. Geochimica and Cosmochimica Acta 58: 249-255.

Charpentier J. 1841. Essaisurles glaciers. Lallsanne, Duclou.

Czernicka-Chodkowska D. 1977. Zabytkowe głazy narzutowe na obszarze Polski. Katalog cz. I i II. Wyd. Geol., Warszawa.

Czernicka-Chodkowska D. 1983. Zabytkowe głazy narzutowe na obszarze Polski. Katalog cz. IV. Wyd. Geol., Warszawa.

Czubla P. 2001. Eratyki fennoskandzkie w utworach czwartorzędowych Polski środkowej i ich zna- 
czenie stratygraficzne. Acta Geographica Lodziensia 80.

Czubla P. 2015. Eratyki fennoskandzkie w osadach glacjalnych Polski i ich znaczenie badawcze. Wydawnictwo Uniwersytetu Łódzkiego, Łódź.

Czubla P., Gałązka D., Górska M. 2006. Eratyki przewodnie w glinach morenowych Polski. Przeglad Geologiczny 54(4): 352-362.

Darvill C.M. 2013. Cosmogenic nuclide analysis. W: L.E. Clarke, J.N. Nield (red.) Geomorphological Techniques. British Society for Geomorphology, London, UK: 364-388.

Dunai T. 2010. Cosmogenic Nuclides. Principles, Concepts and Applications in the Earth Surface Sciences. Cambridge: Cambridge University Press.

Dzierżek J., Zreda M. 2007. Timing and style of deglaciation of northeastern Poland from cosmogenic ${ }^{36} \mathrm{Cl}$ dating of glacial and glaciofluvial deposits. Geological Quarterly 51: 203-216.

Dzierżek J., Nitychoruk J., Zreda M., Zreda-Gostyńska G. 1996. Cosmogenic isotope ${ }^{36} \mathrm{Cl}$ - a new perspective for Quaternary chronostratigraphy of Poland. Geological Quarterly 40(3): 481-486.

Dzierżek J., Nitychoruk J., Zreda-Gostyńska G., Zreda M. 1999. Metoda datowania kosmogenicznym izotopem ${ }^{36} \mathrm{Cl}$ - nowe dane do chronologii glacjalnej Tatr Wysokich. Przegląd Geologiczny 47(11): 987-992.

Gołębiewski R., Dworniczak J., Tylmann W., Woźniak P.P. 2005. Rzeźba zlewni górnej Raduni. W: W. Lange (red.) Jeziora górnej Raduni i jej zlewnia w badaniach z udziatem Stacji Limnologicznej w Borucinie. Badania Limnologiczne 3. Katedra Limnologii UG, Gdańsk: 59-74.

Gosse J.C., Evenson E.B., Klein J., Lawn B., Middleton R. 1995. Precise cosmogenic ${ }^{10} \mathrm{Be}$ measurements in western North America: support for a global Younger Dryas cooling event. Geology 23: 877-880.

Gotlib D., Olszewski R. 2006. Co z trzecim wymiarem? Geodeta 4(131): 31-34.

Graf A.A., Strasky S., Ivy-Ochs S., Akçar N., Kubik P., Burkhard M., Schlüchter C. 2007. First results of cosmogenic dated pre-Last Glaciation erratics from the Montoz area, Jura Mountains, Switzerland. Quaternary International 164165: 43-52.

Górska-Zabielska M. 2008. Fennoskandzkie obszary alimentacyjne osadów akumulacji glacjalnej i glacjofluwialnej lobu Odry. Wyd. Nauk. UAM, Poznań.

Górska-Zabielska M. 2015. Najcenniejsze głazy narzutowe w Wielkopolsce i ich potencjał geoturystyczny. Przegląd Geologiczny 63(8): 455463.

Górska-Zabielska M. 2016. Głazy narzutowe Drawieńskiego Parku Narodowego i ich znaczenie w rozwoju lokalnej geoturystyki. Przegląd Geologiczny 64(10): 844-847.
Heine K., Reuther A.U., Thieke H.U., Schulz R., Schlaak N., Kubik P.W. 2009. Timing of Weichselian ice marginal positions in Brandenburg (northeastern Germany) using cosmogenic in situ ${ }^{10} \mathrm{Be}$. Zeitschrift für Geomorphologie NF 53(4): 433-454.

Hermann R. 1911. Die erratischen Blöcke im Regierungsbezirk Danzig. Beiträge zur Naturdenkmalpflege 2(1): 1-108.

Heyman J., Stroeven A.P., Harbor J.M., Caffee M.W. 2011. Too young or too old: Evaluating cosmogenic exposure dating based on an analysis of compiled boulder exposure ages. Earth and Planetary Science Letters 302: 71-80.

Houmark-Nielsen M., Linge H., Fabel D., Schnabel C., Xu S., Wilcken K.M., Binnie S. 2012. Cosmogenic surface exposure dating the last deglaciation in Denmark: Discrepancies with independent age constraints suggest delayed periglacial landform stabilisation. Quaternary Geochronology 13: 1-17.

Ilewicz P.K., Kobiela M.H. 2014. Określenie przydatności głazów narzutowych w woj. pomorskim do datowań metodą kosmogenicznych nuklidów. Maszynopis pracy licencjackiej, Archiwum UG, Gdańsk.

Ivy-Ochs S., Briner J.P. 2014. Dating Disappearing Ice. Elements 10: 351-356.

Ivy-Ochs S., Kober F. 2008. Surface exposure dating with cosmogenic nuclides. Quaternary Science Journal 57(1-2): 179-209.

Jasiewicz J. 2005. Stratygrafia glin morenowych i struktura glacitektoniczna gardnieńskiej moreny czołowej. Prace Komisji Geograficzno-Geologicznej 37, Poznańskie Towarzystwo Przyjaciół Nauk, Poznań.

Kondracki J. 2002. Geografia regionalna Polski. PWN, Warszawa.

Kozarski S. 1995. Deglacjacja Polski północno-zachodniej: warunki środowiska i transformacja geosystemu ( $\sim 20 \mathrm{ka} \rightarrow 10 \mathrm{ka} \mathrm{BP})$. Dokumentacja Geograficzna 1.

Kurtz M.D., Brook E.J. 1994. Surface Exposure Dating with Cosmogenic Nuclides. W: Ch. Beck (red.) Dating in Exposed and Surface Context. University of New Mexico Press. Albuquerque: 139-159.

Lorenc H. (red.) 2005. Atlas klimatu Polski. Instytut Meteorologii i Gospodarki Wodnej. Warszawa.

Makos M., Nitychoruk J., Zreda M. 2013a. Deglaciation chronology and paleoclimate of the Pięciu Stawów Polskich/Roztoki Valley, high Tatra Mountains, Western Carpathians, since the Last Glacial Maximum, inferred from ${ }^{36} \mathrm{Cl}$ exposure dating and glacier-climate modelling. Quaternary International 293: 63-78.

Makos M., Nitychoruk J., Zreda M. 2013b. The Younger Dryas climatic conditions in the Za Mnichem Valley (Polish High Tatra Moun- 
tains) based on exposure-age dating and glacier-climate modelling. Boreas 42: 745-761.

Makos M., Rinterknecht V., Braucher R., Żarnowski M., Aster Team 2016. Glacial chronology and palaeoclimate in the Bystra catchment, Western Tatra Mountains (Poland) during the Late Pleistocene. Quaternary Science Reviews 134: 74-91.

Makosz E., Stanienda K. 2012. Walory geoturystyczne skandynawskich eratyków rejonu Gliwic. Górnictwo i Geologia 7(3): 57-72.

Makowska A. 1999. Szczegółowa mapa geologiczna Polski w skali 1:50 000, ark. Elbląg Północ. Wydawnictwo Geologiczne. Warszawa.

Marks L., Ber A., Gogołek W., Piotrowska K. (red.) 2006. Mapa Geologiczna Polski 1:500 000. Ministerstwo Środowiska, PIG-PIB, Warszawa.

Mojski J.E. 2005. Ziemie polskie w czwartorzędzie. Zarys morfogenezy. PIG, Warszawa.

Plug L.J., Gosse J.C., Mcintosh J.J., Bigley R. 2007. Attenuation of cosmic ray flux in temperate forests. Journal of Geophysical Research 112 (2): 1-9.

Reuther A.U., Ivy-Ochs S., Heine K. 2006. Application of surface exposure dating in glacial geomorphology and the interpretation of moraine ages. Zeitschrift für Geomorphologie, Supplement 142: 335-359.

Rinterknecht V.R., Börner, A., Bourlès D., Braucher R. 2014. Cosmogenic ${ }^{10} \mathrm{Be}$ dating of ice sheet marginal belts in Mecklenburg-Vorpommern, Western Pomerania (northeast Germany). Quaternary Geochronology 19: 42-51.

Rinterknecht V., Braucher R., Böse, M., Bourlès D., Mercier J.L. 2012. Late Quaternary ice sheet extents in northeastern Germany inferred from surface exposure dating. Quaternary Science Reviews 44: 89-95.

Rinterknecht V.R., Marks L., Piotrowski J.A., Raisbeck G.M., Yiou F., Brook E.J. \& Clark P.U. 2005. Cosmogenic ${ }^{10} \mathrm{Be}$ ages on the Pomeranian moraine, Poland. Boreas 34: 186-191.

Rudolph F. 1994. Die Trilobiten der mittelkambrischen Geschiebe - Systematik, Morhologie und Ökologie. Verlag F. Rudolph, Wankendorf.

Sauter M. 2015. Odporność głazów narzutowych w rejonie Doliny Gniewowskiej (Pojezierze Kaszubskie) w świetle testów młotkiem Schmidta. Praca licencjacka, Archiwum UG, Gdańsk.

Schallreuter R. 1994. Schwarze Orthocerenkalk-Geschiebe. Archiv für Geschiebekunde 1(8/9): 491540.

Schulz W. 2003. Geologischer Führer für den norddeutschen Geschiebesammler. cw Verlagsgruppe, Schwerin.

Siemiradzki J. 1882. Nasze głazy narzutowe. Pamiętnik Fizjograficzny 2: 87-122.

Small D., Clark C.D., Chiverrell R.C., Smedley R.K., Bateman M.D., Duller G.A.T., Ely J.C., Fabel D., Medialdea A., Moreton S.G. 2017. Devising quality assurance procedures for assessment of legacy geochronological data relating to deglaciation of the last British-Irish Ice Sheet. Earth Science Reviews 164: 232-250.

Stasińska A. 1967. Tabulata from Norway, Sweden and from the erratic boulders of Poland. Palaeontologica Polonica 18: 1-112.

Szarzyńska A., Ziółkowski P. 2012. Skandynawskie dary. Głazy narzutowe Warmii i Mazur. Wydawnictwo Mantis, Olsztyn.

Woźniak P.P. 2014. Kształtowanie się rzeźby i profilu osadów na Pobrzeżu Kaszubskim w czasie zlodowacenia wisły - zarys głównych problemów. W: R.J. Sokołowski (red.) Ewolucja środowisk sedymentacyjnych regionu Pobrzeża Kaszubskiego. Wydział Oceanografii i Geografii, Gdynia: 17-26.

Woźniak P.P., Czubla P. 2015. The Late Weichselian glacial record in northern Poland: A new look at debris transport routes by the Fennoscandian Ice Sheet. Quaternary International 386: 3-17.

Woźniak P.P., Tylmann K., Kobiela A. 2015. Głazy narzutowe Trójmiejskiego Parku Krajobrazowego - potencjał badawczy i geoturystyczny. Przeglad Geologiczny 63(4): 256-262.

\section{Summary}

For a long time, large erratics have been a subject of interest for geologists and geographers. In the XIX century, huge blocks of Scandinavian rocks spread on the surface of the European Lowland were one of the strongest arguments supporting the theory of the Pleistocene continental glaciations. Moreover, erratic boulders of crystalline and sedimentary rocks have been an excellent material for mineralogical or paleontological studies. For decades, the erratic debris spread within the glacial till layers has been used in Poland for the reconstruction of the directions of the Scandinavian Ice Sheet transgressions and petrographic characteristics of the till horizons from various glaciations. Large erratic boulders resting in-situ on the surface of glacial landforms may be a target of the surface exposure age dating with terrestrial cosmogenic nuclides (Terrestrial Cosmogenic Nuclides - TCN). This relatively new geochronological technique enables the direct dating of glacial landforms (e.g. moraines), which is crucial for the construction of reliable chronologies of the retreat of paleo-ice sheets. However, especially within the regions of the Pleistocene continental glaciations such as north Poland, the suitability of erratic boulders for exposure age dating with TCN must be carefully inspected, because many factors may influence 
the boulders and complicate their "exposure history".

This paper presents the method and the results of the selection of erratics in Pomerania for exposure age dating with TCN. Middle and eastern Pomerania are key regions to complete the cosmogenic chronologies of the geomorphology left by the last Scandinavian Ice Sheet retreat in the northern Polish landscape. Moreover, it is a region of very fresh glacial landscape with very distinctive landforms and high concentration of erratic debris on the terrain surface. These are the traces of the Pomeranian Phase of the last glaciation - the last significant glacial phase for northern Poland.

Our selection of massive erratics consists of two stages. First, a GIS database (254 erratics) was constructed based on all the available information about large boulders, and the erratics were selected based on their dimensions and distribution against a digital elevation model and geologic maps. This desk-based filtering of the dataset was a crucial stage of our research, resulting in a significant reduction of the number of erratics suitable for field inspection and as a consequence saving the time and resources for fieldwork. Second, field inspection of preliminarily selected boulders (57) was conducted and 27 erratics were finally selected as suitable for surface exposure age dating with TCN. The significant reduction of the number of boulders at particular stages of qualification shows the importance of the proposed systematic selection. Spatial distribution of the selected boulders (location on moraine plateaux and paleo ice-marginal belts) and their individual features show their high usefulness for surface exposure age dating with TCN. 